\title{
Multilocus Sequence Typing of Strains of Bacterial Spot of Lettuce Collected in the United States
}

\author{
Joubert Fayette, Richard Raid, Pamela D. Roberts, Jeffrey B. Jones, Ken Pernezny, Carolee T. Bull, and Erica M. Goss
}

First, second, and fifth authors: Everglades Research and Education Center, University of Florida Institute of Food and Agricultural Sciences (IFAS), Belle Glade; third author: Southwest Florida Research and Education Center, University of Florida/IFAS, Immokalee; first, second, third, fourth, fifth, and seventh authors: Department of Plant Pathology, University of Florida, Gainesville; sixth author: United States Department of Agriculture-Agricultural Research Service, Pacific West Area, 1636 E. Alisal St., Salinas, CA; and seventh author: Emerging Pathogens Institute, University of Florida, Gainesville.

Current address of C. T. Bull: Department of Plant Pathology and Environmental Microbiology, Pennsylvania State University, University Park. Accepted for publication 21 June 2016.

\begin{abstract}
Fayette, J., Raid, R., Roberts, P. D., Jones, J. B., Pernezny, K., Bull, C. T., Goss, E. M. 2016. Multilocus sequence typing of strains of bacterial spot of lettuce collected in the United States. Phytopathology 106:1262-1269.

Studies on genetic diversity and recombination in bacterial pathogens are providing a better understanding of the mechanisms shaping bacterial diversity, which can affect disease control. Xanthomonas campestris pv. vitians, causal agent of bacterial leaf spot of lettuce, is a threat to the worldwide lettuce industry. We examined the genetic variation within a sample of 83 strains from California, Florida, and Ohio using multilocus sequence typing of six housekeeping genes, totaling $2.7 \mathrm{~kb}$. Additionally, polymorphism in two virulence-related genes, $h r p B 2$ and a putative glycosyl

hydrolase, were examined. Based on housekeeping genes, we found three genetic groups of strains that were all able to induce the disease. These included strains collected from weeds and irrigation water that had haplotypes identical to strains from diseased lettuce. High linkage disequilibrium across the sequenced loci indicates that the pathogen is predominantly clonal but recombination has contributed to the observed sequence variation. Although there was significant genetic variation in X. campestris pv. vitians within and among sampled states, identical haplotypes were observed across all three states. This finding suggests that seedborne inoculum may contribute to the diversity of $X$. campestris pv. vitians in the United States. Knowledge of the genetic structure of the pathogen may be used for developing resistant lettuce varieties.
\end{abstract}

First reported in South Carolina in 1916 (Brown 1918), Xanthomonas campestris pv. vitians, causal agent of bacterial leaf spot of lettuce, has recently become a potential threat to the lettuce industry in many parts of the world, including North America (Burkholder 1954; Pernezny et al. 1995; Toussaint 1999), Africa (Yigit 2011), Asia (Sahin 2000; Myung et al. 2010), and Europe (Sahin 2000; Zoina and Volpe 1994). Control of this disease with bactericides is difficult; thus, there is a need to identify host resistance (Bull et al. 2015; Wang et al. 2015). When lettuce cultivars and lines were screened for resistance to three single strains of $X$. campestris pv. vitians, disease incidence and severity showed a lettuce genotype by $X$. campestris pv. vitians strain interaction (Wang et al. 2015). This result suggests that genetic variation in $X$. campestris pv. vitians should be considered when developing management strategies based on host resistance.

The causal agent of the bacterial leaf spot of lettuce pathogen has created some confusion. Analysis of a large number of genetically diverse Xanthomonas strains from many plant species in 1995 reclassified the $X$. campestris pv. vitians pathotype strain LMG 937 $($ NCPPB $976=$ ATCC 19320) as $X$. axonopodis pv. vitians, while another bacterial spot of lettuce strain, LMG 938, was placed in $X$. hortorum (Vauterin et al. 1995). Subsequent studies showed that strain LMG 937 was genetically different from pathogenic strains collected from diseased lettuce, including LMG 938, and was not pathogenic on lettuce but weakly pathogenic on tomato and

Corresponding author: E. M. Goss; E-mail address: emgoss@ufl.edu

*The $\boldsymbol{e}$-Xtra logo stands for "electronic extra" and indicates that two supplementary files are published online.

http://dx.doi.org/10.1094/PHYTO-11-15-0302-R

(C) 2016 The American Phytopathological Society pepper (Barak et al. 2001; Sahin et al. 2003). Although the strains associated with lettuce were reclassified, the pathogenic strains continue to be referred to as $X$. campestris pv. vitians.

Investigation of the diversity of $X$. campestris pv. vitians strains isolated from lettuce in Ohio further distinguished two phenotypic and genetic groups similar to LMG 938 (Sahin et al. 2003). The grouping was based on pathogenicity tests, monoclonal antibodies, fatty acid methyl ester analysis, sodium dodecyl sulfate polyacrylamide gel electrophoresis, and BIOLOG profiles. Group A strains were reported to produce local and systemic symptoms on lettuce leaves and blight on stems, whereas group B strains caused necrotic spots on leaves (Sahin et al. 2003). No sequence variation was found in the 16S-23S ribosomal DNA spacer regions of representative strains. Another study also found that the spacer regions of strains from different geographical regions were similar and that there was no genetic evidence for different groupings of Xanthomonas spp. associated with bacterial leaf spot of lettuce, based on repetitive element polymerase chain reaction (rep-PCR) and whole-genome genetic fingerprinting (Barak and Gilbertson 2003).

Multilocus sequence typing (MLST) was proposed in 1998 as an approach to identify clones within populations of pathogenic microbes (Maiden et al. 1998). It consists of the sequencing of multiple housekeeping genes whose evolution is either neutral or selectively constrained (Sarkar and Guttman 2004). The variants at each locus are given different allele numbers and each strain is defined by its allelic profile across the sequenced loci, known as the sequence type (ST) (Feil et al. 2003; Maiden 2006; Scally et al. 2005). Multilocus sequence analysis (MLSA) uses the same data set of housekeeping gene sequences but differs in that the analysis uses nucleotide sequences rather than simply the ST. Since 1998, MLSA has been extensively used to study bacterial population structure and evolution (Cooper and Feil 2004; Didelot and Falush 2007; Yan 
et al. 2008). MLST schemes have been developed for Pseudomonas syringae (Bull et al. 2011; Hwang et al. 2005; Morris et al. 2008), Ralstonia solanacearum (Castillo and Greenberg 2007), Xylella spp. (Scally et al. 2005), and xanthomonads (Almeida et al. 2010; Young et al. 2008), among others.

Bacteria reproduce clonally but their genomes can be modified through the exchange of gene fragments. Horizontal gene transfer has affected the evolution of Xanthomonas genomes (Lima et al. 2008; Lin et al. 1999). Horizontal gene transfer has acted on genes involved in pathogenicity as well as housekeeping genes (Mhedbi-Hajri et al. 2013). MLSA has been useful in the estimation of relative contributions of mutation and recombination to the evolution of bacterial plant pathogens (Goss et al. 2005; Sarkar and Guttman 2004; Smith 1999).

Variation has or has not been observed in population samples of $X$. campestris pv. vitians depending on the sample and the electrophoretic and phenotypic markers used (Barak and Gilbertson 2003; Sahin et al. 2003). MLST has not previously been applied to study diversity in $X$. campestris pv. vitians and there is a need to study this pathogen using a multilocus approach to unambiguously assign ST and discriminate among differentiated groups of strains. We examined the population structure of $X$. campestris pv. vitians in the United States, as represented by strains from California, Florida, and Ohio, using MLST and MLSA. Our objectives were to determine the level of genetic variation in X. campestris pv. vitians within states and genetic differentiation among states, examine the support from MLSA analysis of housekeeping genes for two genetic groups consistent with the previous A/B grouping described by Sahin et al. (2003), and estimate the role of recombination in generating variation in $X$. campestris pv. vitians. Based on previous population studies (Barak and Gilbertson 2003; Sahin et al. 2003) and plant resistance screening in Florida (Wang et al. 2015), we hypothesized that $X$. campestris pv. vitians would exhibit little genetic variation in California but two differentiated genetic groups in Ohio and possibly Florida.

\section{MATERIALS AND METHODS}

Bacterial strains. The $X$. campestris $p v$. vitians strains, including their sources, year of isolation, and geographical origin, used in this study are listed in Table 1 . The strains primarily came from three sources: diseased lettuce (representing many cultivars), epiphytic populations on symptomless weeds, and irrigation water. Florida samples from 2010 to 2014 were collected from three commercial farms in the Everglades Agricultural Area (EAA). Strains from weeds and irrigation water were collected as part of an ecological study of bacterial leaf spot of lettuce (Fayette 2014). Strains were identified as $X$. campestris pv. vitians based on amplification of an $X$. campestris pv. vitians-specific fragment using the B162 primer pair (Barak et al. 2001) or the F-glyco and R-glyco primer pair (see below), and the sequence of $h r p B$ (Obradovic et al. 2004). For long-term storage, bacterial strains were stored in sterile $15 \%$ aqueous glycerol solution at $-80^{\circ} \mathrm{C}$. Working cultures were kept on nutrient agar slants.

Pathogenicity test. Strains were grown on nutrient agar and incubated at $28^{\circ} \mathrm{C}$. Each strain collected in the Florida EAA was tested for pathogenicity in crisphead 'Belle Glade' and romaine 'Okechobee' lettuce cultivars. Plants were grown in a greenhouse in $10-\mathrm{cm}$ pots containing Fafard 2 Mix, a mixture of Canadian sphagnum peat, perlite, and vermiculite (Conrad Fafard, Inc., Agawan, MA). Plants were grown for 4 to 5 weeks. They were inoculated with a hand sprayer until run-off with a bacterial suspension adjusted to $1 \times 10^{8} \mathrm{CFU} \mathrm{ml}^{-1}$ (absorbance at $600 \mathrm{~nm}=0.3$ ) obtained from 24-h culture. The positive control consisted of plants inoculated with known pathogenic $X$. campestris pv. vitians strain L7 (Pernezny et al. 1995), whereas plants inoculated with tap water constituted the negative control. Plants were bagged and placed in a growth room adjusted to $21^{\circ} \mathrm{C}$ (Robinson et al. 2006). After $48 \mathrm{~h}$, bags were removed and plants were returned to the greenhouse for the remainder of each experiment. Fourteen days after inoculation, plants were evaluated for the presence or absence of disease symptoms.

Amplification and sequencing of genes. Six primer pairs (lacF, gyrB, gltA, gap-1, fusA, and lepA) designed for MLST of Xanthomonas spp. (Almeida et al. 2010) were used in this study. Two additional gene fragments were also sequenced. These were the type III secretion system gene $h r p B 2$ (Obradovic et al. 2004), and a putative glycosyl hydrolase gene, designated $J F 1$ here, which was originally identified as a random amplified polymorphic DNA product found in

TABLE 1. Strains of Xanthomonas campestris pv. vitians used in this study

\begin{tabular}{|c|c|c|c|c|}
\hline Strain designation & Source $^{\mathrm{a}}$ & Origin & Year $^{\mathrm{b}}$ & Reference \\
\hline LMG 938 & Lettuce & Zimbabwe & 1965 & Vauterin et al. 1995 \\
\hline L41, L43, L44 & Lettuce & Florida & 1993 & Pernezny et al. 1995 \\
\hline B55 & Lettuce & California & 1994 & Sahin et al. 2003 \\
\hline $906,917,919,921,923,924$ & Lettuce & Ohio & 1996 & Sahin et al. 2003 \\
\hline B57 & Lettuce & California & 1996 & Sahin et al. 2003 \\
\hline B59 & Lettuce & California & 1997 & Sahin et al. 2003 \\
\hline L1, L2, L3, L7, L11, L13, X251, X252, X253 & Lettuce & Florida & 1998 & Pernezny et al. 1995 \\
\hline BS2861 & Lettuce & California & 2010 & S. Koike \\
\hline JF150, JF152, JF154 & Lettuce & Florida & 2010 & This study \\
\hline $\begin{array}{l}\text { JF52, JF58, JF70, JF72, JF74, JF88, JF90, JF116, JF156, JF158, JF160, JF168, } \\
\text { JF180, JF182, JF184 }\end{array}$ & Lettuce & Florida & 2011 & This study \\
\hline $\begin{array}{l}\text { JF170, JF172, JF174, JF176, JF178, JF178, JF186, JF188, JF196, JF200, JF202, } \\
\text { JF204, JF206, JF208, JF210, JF214 }\end{array}$ & Lettuce & Florida & 2012 & This study \\
\hline JF162, JF164, JF166, JF190, JF192, JF198 & Lettuce & Florida ${ }^{\mathrm{c}}$ & 2012 & This study \\
\hline W17, W18, W21, W28 & Weeds & Florida & 2013 & This study \\
\hline
\end{tabular}

${ }^{a}$ Isolation host. Weeds = strains from weeds isolated from the following species: Lactuca seriola (W3), Sonchus oleraceus (W5, W15, and W28), Solanum americanum (W17, W18), Chenopodium album (W8), Amaranthus spinosus (W13), Eclipta prostrata $(\mathrm{W} 14)$, and Portulaca oleracea $(\mathrm{W} 21)$. Water $=$ irrigation water.

b Year isolated.

${ }^{\mathrm{c}}$ Strains were collected from lettuce in a Florida supermarket. 
$X$. campestris pv. vitians strains (Barak et al. 2001). We amplified and sequenced JF1 using the PCR primers designed by Barak et al. (2001), and used the sequence to design new internal primers for sequence analysis: F-glyco 5'-CTGCTGATTGCGACGGACAATGAGG-3' and R-glyco 5'-CGCGATATCGATTGCGAAGGCTTGG -3'.

Genomic DNA was extracted using the Qiagen DNeasy Plant mini kit or NucleoSpin Tissue kit (Macherey-Nagel, Deer Park, NY). DNA template was added to PCR reagents of $1.25 \mathrm{U}$ of Taq DNA polymerase (Qiagen, Macherey-Nagel) in $1 \times$ Taq Buffer, $0.2 \mathrm{mM}$ dNTP, the primers, and water, for a final reaction volume of $25 \mu \mathrm{l}$. Amount of primers used varied among primer pairs (Almeida et al. 2010). For $h r p B$ and $J F 1$, the primer concentration was $0.5 \mathrm{mM}$. After a hot start at $95^{\circ} \mathrm{C}$ for $30 \mathrm{~s}$ followed by the denaturation for $5 \mathrm{~min}$ at $95^{\circ} \mathrm{C}$, the amplification profile was 30 cycles of $95^{\circ} \mathrm{C}$ for $45 \mathrm{~s}, 58^{\circ} \mathrm{C}$ for $30 \mathrm{~s}$, and $72^{\circ} \mathrm{C}$ for $30 \mathrm{~s}$, which was followed by an extension time of $5 \mathrm{~min}$ at $72^{\circ} \mathrm{C}$. Amplified DNA fragments were inspected by gel electrophoresis in a $1.0 \%$ agarose gel in 0.5 Tris-borate EDTA buffer. ExoSAP-It (Amersham Biosciences, Piscataway, NJ) was used to prepare the PCR products for sequencing following the manufacturer's instructions. The products were sequenced in both directions at the Interdisciplinary Center for Biotechnology Research, University of Florida. Reads were assembled and edited using Phred and Phrap implemented in CodonCode Aligner (CodonCode Corporation, Dedham, MA). Contigs were aligned using Clustal $\mathrm{W}$ and trimmed to the desired length. Sequences representing each haplotype were deposited in the National Center for Biotechnology Information GenBank under accessions KU095848 to KU095849 and KU136320 to KU136335. Sequences for the concatenated MLST loci and for the JF1 locus for all strains are provided as Supplementary Files S1 and S2.

Population genetic analysis. Statistics summarizing nucleotide diversity and number of polymorphic sites were estimated for each gene. MLST uses housekeeping genes representative of the core genome of the species. Housekeeping genes are generally expected to be under purifying selection. Tajima's D statistic is based on differences between two estimators of nucleotide polymorphism, Washington's $\theta\left(\theta_{\mathrm{w}}\right)$ and nucleotide diversity $\left(\theta_{\pi}\right)$. If Tajima's D is significantly different from zero, the null hypothesis of neutral evolution is rejected. A significantly negative D can be an indication of a selective sweep or population growth, whereas a positive $\mathrm{D}$ can result from diversifying selection. Fu and Li's tests are particularly useful for the detection of rare alleles or young mutations, genetic hitchhiking, and population expansion (Fu 1996; Kreitman 2000). MLST sequences were tested for departure from neutral evolution using Tajima's D (Tajima 1989), Fu and Li' D* and $\mathrm{Fu}$ and $\mathrm{Li}^{\prime} \mathrm{F}^{*}$ (Fu and $\mathrm{Li}$ 1993). The tests of neutrality were conducted in DnaSP (Librado and Rozas 2009). Assignments of alleles to ST were made through the MLST nonredundant database program (http://pubmlst.org). To test for linkage disequilibrium among loci, the index of association was estimated in LIAN 3.7 (Haubold and Hudson 2000, Smith et al. 1993).

Population structure. Genetic variation between and within populations was evaluated by analysis of molecular variance
(AMOVA) carried out using the software Arlequin 3.5 (Excoffier et al. 2005). The software Sequence Matrix (Vaidya et al. 2011) was used to concatenate the MLST fragments. The strains were divided into three groups: Florida $(n=57)$, Ohio $(n=13)$, and California $(n=$ $12)$. The fixation index $\left(\mathrm{F}_{\mathrm{ST}}\right)$, a measure of population differentiation due to genetic structure, was also estimated.

Phylogenetic analysis. The phylogenetic relationship among strains was estimated by maximum-likelihood phylogenetic analysis. jModeltest was used to determine an appropriate nucleotide substitution model for the concatenated sequences by evaluating 88 substitution models using maximum-likelihood with nearest neighbor interchange (NNI) tree searching. The best model was selected using the corrected Akaike information criterion. The maximum-likelihood phylogeny was inferred using PhyML with the TPM2uf substitution model and NNI tree searching, as implemented in Geneious 6.1.6 (Biomatters Ltd., Auckland, New Zealand). Branch support was assessed with 500 bootstrap samples.

Coalescent analysis. The clonal genealogy of the strains was estimated in ClonalFrame, which uses a coalescent-based population model to infer the evolutionary history of bacterial populations that are predominantly clonal (Didelot and Falush 2007). The Markov Chain Monte Carlo (MCMC) simulation was run with the following parameters: 100,000 MCMC iterations after a burn-in period of 100,000 iterations. The thinning interval was 100 , which provided independent successive samplings. Two independent simulations were carried out to check the convergence of parameters. The statistic $\rho / \theta$ is the ratio of rates of recombination relative to mutation, and $r / m$ is a measure of the impact of recombination $(r)$ relative to mutation $(m)$. Parameters were also estimated using ClonalFrameML using $\kappa=2.454$ and 1,000 pseudoreplicates for bootstrapping (Didelot and Wilson 2015).

Recombination. The software packages RDP4 (Martin et al. 2010) and DnaSP were also used to detect recombination events. To estimate the mutation rate and recombination rate for each locus in $\mathrm{RDP} 4$, the default values for a recombination rate plot were chosen. The settings were starting $\rho=30$, block penalty $=10$, minor allele frequency cutoff $=0.05$, average gene conversion tract length $=$ 1,000, MCMC updates 100,000, and MCMC burn-in 100,000. For

TABLE 3. Results of neutrality tests ${ }^{\mathrm{a}}$

\begin{tabular}{lccc}
\hline Gene & Tajima's D & Fu and Li's D* & Fu and Li's F* \\
\hline fusA & -0.51 & 0.504 & 0.235 \\
gap-1 & $3.896^{* *}$ & 1.381 & $2.663^{* *}$ \\
glta & -1.216 & 0.700 & 0.135 \\
gyrB & -1.774 & $-4.577^{* *}$ & $-4.267^{* *}$ \\
lacF & $-1.882^{* *}$ & $-3.098^{* *}$ & $-3.182^{* *}$ \\
lepA & -1.048 & -1.982 & -1.982 \\
Concatenated MLST loci & -0.008 & -2.677 & -1.898 \\
JF1 & 1.383 & 0.525 & 0.899 \\
\hline
\end{tabular}

${ }^{a}$ MLST $=$ multilocus sequence typing. Asterisks $(* *)$ indicate statistical significance: $P<0.01$ for Tajima's D and $P<0.02$ for Fu and Li's statistics.

TABLE 2. Polymorphism statistics for all sequenced loci

\begin{tabular}{|c|c|c|c|c|c|c|}
\hline Gene & Number of sequences & Length & Number of haplotypes & Haplotype diversity & $\theta_{\pi^{\mathrm{a}}}$ & $\theta_{\mathrm{w}}{ }^{\mathrm{b}}$ \\
\hline fusA & 83 & 591 & 2 & 0.115 & 0.0002 & 0.0003 \\
\hline gap-1 & 83 & 444 & 3 & 0.637 & 0.0112 & 0.0045 \\
\hline gltA & 83 & 501 & 2 & 0.048 & 0.0002 & 0.0007 \\
\hline $\operatorname{lacF}$ & 83 & 408 & 3 & 0.048 & 0.0003 & 0.0025 \\
\hline lepA & 83 & 390 & 2 & 0.049 & 0.0001 & 0.0005 \\
\hline Concatenated MLST loci & 83 & 2745 & 9 & 0.677 & 0.002 & 0.002 \\
\hline$J F 1$ & 62 & 409 & 2 & 0.444 & 0.0005 & 0.0005 \\
\hline
\end{tabular}

a Nucleotide diversity per site using Jukes and Cantor correction factor.

b Watterson's $\theta$ per site.

${ }^{c}$ MLST $=$ multilocus sequence typing. 
analysis in DnaSP, the genomic state and chromosomal location were selected as haploid and prokaryotic, respectively. The minimum number of recombination events (the four-gamete test) (Hudson 1987) was estimated for each MLST locus and the MLST concatenated sequence.

\section{RESULTS}

Pathogenicity. The $X$. campestris pv. vitians strains tested for pathogenicity were recovered from various sources, including leaves with visible symptoms of bacterial leaf spot of lettuce, epiphytic populations on weeds from commercial lettuce farms in the EAA, and irrigation water. Typical bacterial leaf spot symptoms are characterized by dark-brown to dark lesions surrounding by yellow halos on lettuce leaves. All of the Florida strains from 2010 to 2104 produced symptoms similar to those induced by the $X$. campestris pv. vitians strain L7. No symptoms were observed in plants that were inoculated with tap water. Strains from earlier Florida, Ohio, and California collections (Table 1) were previously characterized (Barak and Gilbertson 2003; Pernezny et al. 1995;

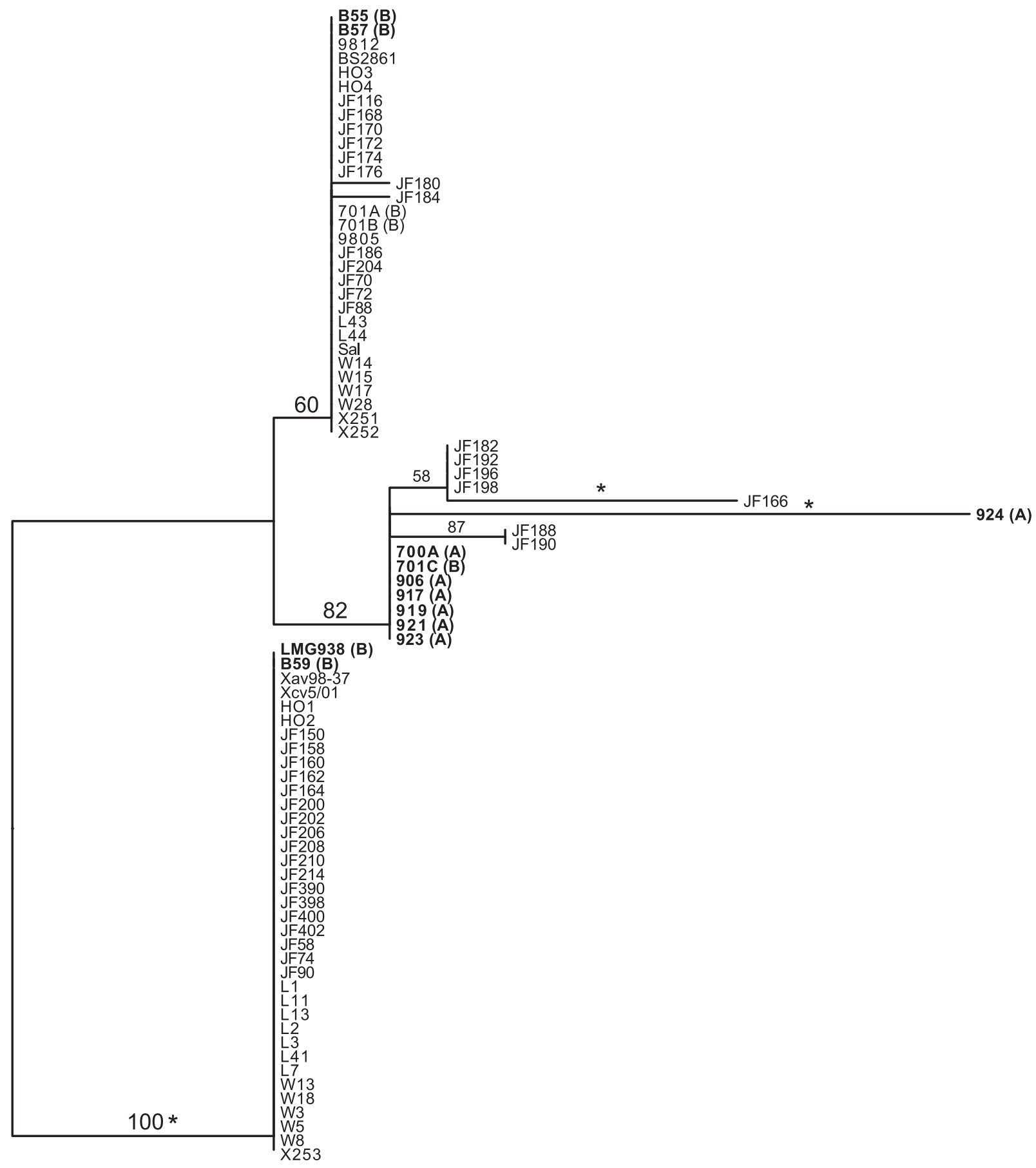

Fig. 1. Maximum-likelihood phylogeny of Xanthomonas campestris pv. vitians strains from California, Florida, and Ohio based on multilocus sequence analysis. Strains previously assigned to two genetic groups by Sahin et al. (2003) are shown in bold, with A/B grouping in parentheses. Bootstrap support values are shown above branches. Recombination was inferred on branches indicated with asterisks. Branch lengths are in substitutions per site. 
Sahin et al. 2003) and include strains representing both groups proposed by Sahin et al. (2003).

Polymorphism. In all, 83 strains of $X$. campestris pv. vitians, including the reference strain LMG 938, were sequenced at six loci for MLSA. The length of the six concatenated loci was 2,745 bp.
These sequences resulted in nine multilocus ST among the 83 strains. Individual MLST loci produced two or three haplotypes. For $h r p B$ and $J F 1,48$ and 62 strains were sequenced. The $h r p B$ locus produced a single haplotype. $J F 1$ produced two haplotypes based on single-nucleotide polymorphisms. The $\theta_{\pi}$ was relatively low for

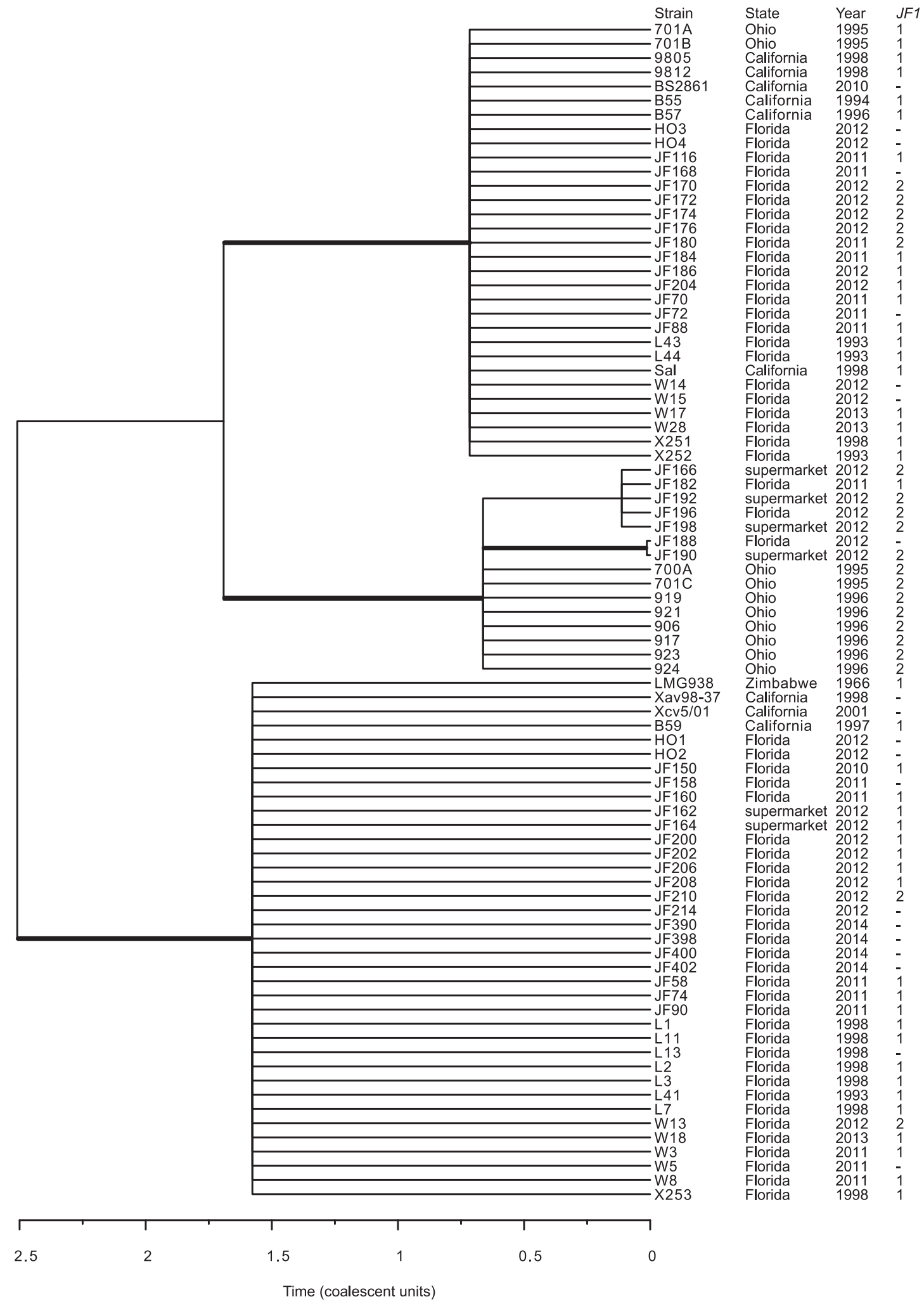

Fig. 2. Consensus clonal genealogy of Xanthomonas campestris pv. vitians strains using multilocus sequence analysis genes. Branches shown were present in at least $50 \%$ of the simulated coalescent genealogies, and branches present in $80 \%$ of genealogies are in bold. The scale indicates time from the present in coalescent units, which is a function of population size and generation time. The collection location and year are shown for strains together with the sequence type of the glycosyl hydrolase gene, $J F 1$. The $J F 1$ sequence was not obtained for all strains. 
each locus (Table 2) and much higher for gap-1 (0.01) than for the other loci ( 0 to 0.002$)$, while $\theta_{\mathrm{w}}$ was high for gap-1 relative to the other loci but $\theta_{\mathrm{w}}$ for $g y r B$ was slightly higher.

The neutrality tests did not reject neutral evolution of the housekeeping genes fusA, gltA, and lepA and the glycosyl hydrolase gene JF1. Only lacf produced significantly negative values for all three neutrality tests, consistent with purifying selection. In contrast, gap -1 had significantly positive values of Tajima's $\mathrm{D}$ and $\mathrm{Fu}$ and Li's F* (Table 3). The statistics were not estimated for hrpB because there was no polymorphism among 48 strains.

Genealogy. The maximum-likelihood phylogeny and clonal genealogy of the MLST loci both supported three groups of strains (Figs. 1 and 2). Strains from California, Ohio, and Florida grouped together in the trees and, in some cases, had identical sequences (Fig. 1). The Sahin et al. (2003) group A strains were all found in one clade but the group B strains were found in all three major clades (Fig. 1). The JF1 locus was not included in the MLST trees; instead, the ST is given in Figure 2 and shows that haplotypes 1 and 2 are found in all three clades.

Recombination. Based on the four-gamete test, a recombination event was detected in the concatenated MLST dataset but not within loci, potentially indicating recombination among loci. The index of association is a commonly used test of recombination in bacteria and measures the degree of linkage among loci. The standardized index of association ( $\mathrm{I}_{\mathrm{SA}}$ ) (Haubold et al. 1998) for the MLST sample was $\mathrm{I}_{\mathrm{SA}}=0.11$. The statistic $\mathrm{I}_{\mathrm{SA}}$ is equal to zero when the population is under free recombination. The observed variance $\left(\mathrm{V}_{\mathrm{D}}=30.46\right)$ was significantly greater than the expected variance under linkage equilibrium $\left(\mathrm{V}_{\mathrm{e}}=6.38\right)$ based on 1,000 trials $(P<$ $0.001)$. The null hypothesis of free recombination among loci was rejected, indicating linkage disequilibrium among loci.

One of the approaches used to examine recombination rates is the estimation of the population recombination rate $(\rho)$ relative to the population mutation rates $(\theta)$, or $\rho / \theta$. The program RDP4 was used to estimate $\rho$ and $\theta$ (Table 4 ). The value of $\rho / \theta$ was $<1$ for $g a p-1$, glta, gyrB, and lacF, averaging 0.0772. Values could not be estimated for the other MLST loci or for JF1. For the concatenated MLST data set, $\rho / \theta=0.0061$.

The $\rho / \theta$ rate was also estimated for the concatenated MLST data set using the coalescent models implemented in ClonalFrame and ClonalFrameML. Significant recombination was found using ClonalFrame $(R=0.868,95 \%$ confidence interval $[0.240$ to $1.745])$. However, the $\rho / \theta$ rate could not be reliably estimated. ClonalFrameML estimated the rate of recombination to have been half the rate of mutation (Table 5). These estimates of recombination are more than an order of magnitude higher than those obtained from RDP4. We calculated the relative impact of recombination to mutation to be $3.2(r / m=R / \theta \times v \times \delta)$, indicating that recombination is responsible for three times as many substitutions as mutation. Recombination events were inferred for strains JF166 and 924, and the branch leading to at least one of the major multilocus ST by both models (Fig. 1). The recombinant sequences were located in lacf, gyrB, and gap-1.

Population structure. We conducted an AMOVA analysis on 57 strains from Florida, 10 strains from Ohio, and 9 from California. The variation between the Florida sample and the combined

TABLE 4. Estimates of recombination and mutation rates

\begin{tabular}{lcccc}
\hline Genes & $\mathrm{Rm}^{\mathrm{a}}$ & $\rho$ & $\theta$ & $\rho / \theta^{\mathrm{b}}$ \\
\hline gap-1 & 0 & 0.0400 & 6.6 & 0.0066 \\
glta & 0 & 0.0350 & 2.0 & 0.0180 \\
gyrB & 0 & 0.0340 & 8.0 & 0.0043 \\
lacF & 0 & 0.9000 & 3.3 & 0.2800 \\
Concatenated loci & 1 & 0.0700 & 11.4 & 0.0061 \\
\hline
\end{tabular}

a Minimum recombination events estimated with DnaSP.

b Estimates of $\rho$ and $\theta$ were obtained in RDP4; $\theta$ is per locus. Parameters could not be estimated for fusA, lepA, JF1, and $h r p B$. other strains was significant at $20 \%$ of the total genetic variation (Table 6). The $\mathrm{F}_{\mathrm{ST}}$ of 0.20 suggests genetic structure but limited variation among groups relative to within groups.

\section{DISCUSSION}

Understanding the diversity of $X$. campestris pv. vitians is important for breeding programs that aim to develop resistant lettuce varieties because of the variation in disease severity that is observed among X. campestris pv. vitians strains (Bull et al. 2015; Sahin et al. 2003; Wang et al. 2015). MLST has been valuable as an unambiguous, highly reproducible tool to assess bacterial diversity and discriminate among different evolutionary lineages that may also differ in phenotype. MLST has not previously been used to examine the diversity of $X$. campestris pv. vitians. MLSA revealed the presence of genetically distinct groups of strains, as previously reported by Sahin et al. (2003). Our analysis supported three groups of strains but there was not a clear relationship between our supported groups and the groups of Sahin and colleagues. Strains from the A group identified by Sahin et al. (2003) were represented by a single multilocus ST but the B group strains produced multiple ST. Florida strains were present in each of the X. campestris pv. vitians genetic clusters. Some of the MLST loci showed little or no variation among strains; therefore, our analysis was largely dependent on variation observed in $g a p-1$ and $g y r B$. This is consistent with the report of Barak and Gilbertson (2003) that $X$. campestris pv. vitians strains constitute a relatively homogenous group, based on pathogenicity, fatty acid profiles, rep-PCR, and internal transcribed spacer sequences.

MLST analyses are based on housekeeping genes, which are expected to be evolutionarily conserved. Housekeeping genes are core genes, which tend to be characterized by clonal descent rather than lateral gene transfer. Core genes can be used to define species boundaries (Goss et al. 2005; Young et al. 2008), and their evolution is usually either neutral or selectively constrained. In contrast, the flexible genome evolves largely via horizontal genetic exchange (Sarkar and Guttman 2004). The glycosyl hydrolase gene (JF1) may be part of the flexible genome but we did not detect departure from neutrality. However, we rejected neutral evolution for some of the housekeeping genes. The MLST genes that had statistically significant values of Tajima's D or Fu and Li's statistics also were the genes that are likely to have undergone recombination. Therefore, the departure from neutrality may be due to the allele frequencies that resulted from rare recombination events. We found only a single haplotype for $h r p B$, suggesting the possibility of strong purifying selection on this gene,

TABLE 5. ClonalFrameML parameter estimates for the concatenated multilocus sequence typing loci

\begin{tabular}{lcc}
\hline Parameters $^{\mathrm{a}}$ & Estimate & $95 \%$ confidence interval \\
\hline $\mathrm{R} / \boldsymbol{\theta}$ & 0.50 & $0.18-1.00$ \\
$\delta$ & 425 & $214-1,175$ \\
$\mathrm{v}$ & 0.015 & $0.009-0.023$ \\
\hline
\end{tabular}

a $\mathrm{R} / \theta$ is the ratio of recombination to mutation, $\delta$ is the average length of a recombination event, and $v$ is the per-site probability of recombination.

TABLE 6. Analysis of molecular variance comparing samples from Florida, Ohio, and California ${ }^{a}$

\begin{tabular}{lrcccc}
\hline $\begin{array}{l}\text { Source of } \\
\text { variation }\end{array}$ & df & $\begin{array}{c}\text { Sum of } \\
\text { squares }\end{array}$ & $\begin{array}{c}\text { Variance } \\
\text { components }\end{array}$ & $\begin{array}{c}\text { Variation } \\
(\%)\end{array}$ & F $_{\text {ST }}$ \\
\hline Among states & 2 & 44.0 & $0.65^{*}$ & 20.08 & 0.20 \\
Within states & 148 & 384.7 & $2.60^{*}$ & 79.92 & $\ldots$ \\
Total & 150 & 428.7 & 3.25 & $\ldots$ & $\ldots$ \\
\hline
\end{tabular}

a Strains were grouped according to their origin: 57 strains from Florida, 10 from Ohio, and 9 from California. An asterisk (*) indicates that variance components were statistically significant. 
which codes for a component of the type III secretion system and is an essential gene for pathogenicity.

The MLSA approach can provide an estimate of the relative contributions of mutation and recombination to bacterial diversification, because MLST loci are core genes found in all strains and they undergo homologous recombination. The ratio of recombination to mutation is commonly averaged across MLST loci (Castillo and Greenberg 2007; Scally et al. 2005). Using this approach, $P$. syringae and Xylella fastidiosa were shown to evolve mainly via mutation (Sarkar and Guttman 2004; Scally et al. 2005). However, recombination was reported to be greater than mutation in bacterial diversification in other plant pathogens, including P. viridiflava (Goss et al. 2005) and Xanthomonas axonopodis pv. vesicatoria (Basim et al. 1999). For X. campestris pv. vitians, we found that mutation occurred at a greater rate than recombination; however, the impact of recombination was greater than the impact of mutation in generating the polymorphism observed in the dataset. We also observed evidence of recombination in comparison to the glycosyl hydrolase gene. These results suggest that recombination is infrequent but has contributed to the genetic variation in $X$. campestris pv. vitians. Based on the clonal genealogy, the most frequently isolated ST, including the type strain, is characterized by a recombination event affecting gap-1. Using a similar analysis for a collection of $X$. axonopodis strains, it was reported that mutation occurs as frequently as recombination, and the impact of recombination was at least three times greater than mutation (Mhedbi-Hajri et al. 2013). Wholegenome sequences for $X$. campestris pv. vitians would provide greater understanding of the impact of recombination on both housekeeping and virulence-related genes.

We found strains with identical ST in Florida, California, and Ohio. In addition, strain LMG 938 collected in 1965 had the same ST as strains found more recently in Florida and California. As bacterial leaf spot of lettuce has recently become more important in Florida (Pernezny et al. 1995), California (Barak and Gilbertson 2003), and Ohio (Sahin et al. 2003), inoculum appears to be moving among production regions. For bacterial spot of tomato and pepper caused by Xanthomonas spp., it has been suggested that the introduction of pepper and tomato seed may serve as sources of races that eventually become endemic in a given production area (Pohronezny et al. 1992). Lettuce in Florida is directly seeded and commercial lettuce seed are mainly produced in California. Infested seed can be produced from diseased lettuce plants (Barak et al. 2002; Sahin and Miller 1997) but X. campestris pv. vitians has not been detected from commercial seed lots (Barak et al. 2001). Based on these MLSA results, two strains from different clades, L7 and JF196 (collected in 1998 and 2012, respectively), were used to screen 30 lettuce genotypes, including crisphead, romaine, butterhead, leaf, and latin types. Strain JF196 was found, overall, to be slightly less virulent than L7 (Wang et al. 2015). Additional tests are required to determine whether strains exhibiting genotypes identical to JF196 and L7 have similar levels of virulence. Continued efforts to identify resistant germplasm may lead to a reduction of inoculum available for seed infestation on resistant cultivars (Bull et al. 2015).

\section{ACKNOWLEDGMENTS}

We thank J. Barak and S. Miller for kindly providing the strains from California and Ohio and anonymous reviewers whose comments improved the manuscript. This research was supported by the University of Florida Institute of Food and Agricultural Sciences Everglades Research and Education Center's Emeritus Faculty Research Endowment.

\section{LITERATURE CITED}

Almeida, N. F., Yan, S., Cai, R., Clarke, C. P., Morris, C. E., Schaad, N. W., Lacy, G. H., Jones, J. B., Castillo, J. A., Bull, C. T., Leman, S., Guttman, D. S., Setubal, J. C., and Vinatzer, B. A. 2010. PAMBD, a multilocus sequence typing and analysis database and website for plant-associated microbes. Phytopathology 100:208-215.
Al-Saleh, M., and Ibrahim, Y. 2009. First report of bacterial leaf spot of lettuce Lactuca sativa caused by Xanthomonas campestris pv. vitians in Saudi Arabia. Plant Dis. 93:107.

Barak, J., and Gilbertson, R. 2003. Genetic diversity of Xanthomonas campestris pv. vitians, the causal agent of bacterial leafspot of lettuce. Phytopathology 93:596-603.

Barak, J., Koike, S., and Gilbertson, R. 2002. Movement of Xanthomonas campestris pv. vitians in the stems of lettuce and seed contamination. Plant Pathol. 51:506-512.

Barak, J. D., Koike, S. T., and Gilbertson, R. L. 2001. Role of crop debris and weeds in the epidemiology of bacterial leaf spot of lettuce in California. Plant Dis. 85:169-178.

Basim, H., Stall, R., Minsavage, G., and Jones, J. 1999. Chromosomal gene transfer by conjugation in the plant pathogen Xanthomonas axonopodis pv. vesicatoria. Phytopathology 89:1044-1049.

Brown, N. A. 1918. Some bacterial diseases of lettuce. J. Agric. Res. 13:367.

Bull, C. T., Clarke, C. R., Cai, R., Vinatzer, B. A., Jardini, T. M., and Koike, S. T. 2011. Multilocus sequence typing of Pseudomonas syringae sensu lato confirms previously described genomospecies and permits rapid identification of $P$. syringae pv. coriandricola and $P$. syringae pv. apii causing bacterial leaf spot on parsley. Phytopathology 101:847-858.

Bull, C. T., Gebben, S. J., Goldman, P. H., Trent, M. A., and Hayes, R. J. 2015. Host genotype and hypersensitive reaction influence population levels of Xanthomonas campestris pv. vitians in lettuce. Phytopathology 105:316-324.

Burkholder, W. 1954. Three bacteria pathogenic on head lettuce in New-York state. Phytopathology 44:592-596.

Castillo, J. A., and Greenberg, J. T. 2007. Evolutionary dynamics of Ralstonia solanacearum. Appl. Environ. Microbiol. 73:1225-1238.

Cooper, J., and Feil, E. 2004. Multilocus sequence typing: What is resolved? Trends Microbiol. 12:373-377.

Didelot, X., and Falush, D. 2007. Inference of bacterial microevolution using multilocus sequence data. Genetics 175:1251-1266.

Didelot, X., and Wilson, D. 2015. ClonalFrameML: Efficient inference of recombination in whole bacterial genomes. PLoS Comput. Biol. 11: e1004041.

Excoffier, L., Laval, G., and Schneider, S. 2005. Arlequin version 3.0: An integrated software package for population genetics data analysis. Evol. Bioinf. Online 1:47-50.

Fayette, J. 2014. The epidemiology, specific detection, genetic variability, and control of Xanthomonas campestris pv. vitians, causal agent of bacterial leaf spot of lettuce. Doctoral dissertation, University of Florida. Online publication. http://ufdc.ufl.edu/UFE0047024/00001

Feil, E. J., Cooper, J. E., Grundmann, H., Robinson, D. A., Enright, M. C., Berendt, T., Peacock, S. J., Smith, J. M., Murphy, M., Spratt, B. G., and Moore, C. E. 2003. How clonal is Staphylococcus aureus? J. Bacteriol. 185: 3307-3316.

Fu, Y. 1996. New statistical tests of neutrality for DNA samples from a population. Genetics 143:557-570.

$\mathrm{Fu}$, Y., and Li, W. 1993. Statistical tests of neutrality of mutations. Genetics 133:693-709.

Goss, E., Kreitman, M., and Bergelson, J. 2005. Genetic diversity, recombination and cryptic clades in Pseudomonas viridiflava infecting natural populations of Arabidopsis thaliana. Genetics 169:21-35.

Haubold, B., Travisano, M., Rainey, P., and Hudson, R. 1998. Detecting linkage disequilibrium in bacterial populations. Genetics 150:1341-1348.

Haubold, H., and Hudson, R. R. 2000. LIAN 3.0: Detecting linkage disequilibrium in multilocus data. Bioinformatics 16:847-849.

Hudson, R. 1987. Estimating the recombination parameter of a finite populationmodel without selection. Genet. Res. 50:245-250.

Hwang, M., Morgan, R., Sarkar, S., Wang, P., and Guttman, D. 2005. Phylogenetic characterization of virulence and resistance phenotypes of Pseudomonas syringae. Appl. Environ. Microbiol. 71:5182-5191.

Kreitman, M. 2000. Methods to detect selection in populations with applications to the human. Annu. Rev. Genomics Hum. Genet. 1:539-559.

Librado, P., and Rozas, J. 2009. DnaSP v5: A software for comprehensive analysis of DNA polymorphism data. Bioinformatics 25:1451-1452.

Lima, W. C., Paquola, A. C. M., Varani, A. M., Van Sluys, M., and Menck, C. F. M. 2008. Laterally transferred genomic islands in Xanthomonadales related to pathogenicity and primary metabolism. FEMS Microbiol. Lett. 281:87-97.

Lin, N. T., Liu, T. J., Lee, T. C., You, B. Y., Yang, M. H., Wen, F. S., and Tseng, Y. H. 1999. The adsorption protein genes of Xanthomonas campestris filamentous phages determining host specificity. J. Bacteriol. 181:2465-2471.

Maiden, M. C. 2006. Multilocus sequence typing of bacteria. Annu. Rev. Microbiol. 60:561-588.

Maiden, M. C., Bygraves, J. A., Feil, E., Morelli, G., Russell, J. E., Urwin, R., Zhang, Q., Zhou, J., Zurth, K., Caugant, D. A., and Feavers, I. M. 1998. Multilocus sequence typing: A portable approach to the identification of clones within populations of pathogenic microorganisms. Proc. Nat. Acad. Sci. USA 95:3140-3145. 
Martin, D. P., Lemey, P., Lott, M., Moulton, V., Posada, D., and Lefeuvre, P. 2010. RDP3: A flexible and fast computer program for analyzing recombination. Bioinformatics 26:2462-2463.

Mhedbi-Hajri, N., Hajri, A., Boureau, T., Darrasse, A., Durand, K., Brin, C., Fischer-Le Saux, M., Manceau, C., Poussier, S., Pruvost, O., and Lemaire, C. 2013. Evolutionary history of the plant pathogenic bacterium Xanthomonas axonopodis. PLoS One 8:e58474.

Morris, C. E., Sands, D. C., Vinatzer, B. A., Glaux, C., Guilbaud, C., Buffiere, A., Yan, S., Dominguez, H., and Thompson, B. M. 2008. The life history of the plant pathogen Pseudomonas syringae is linked to the water cycle. ISME J. 2:321-334.

Myung, I., Moon, S. Y., Jeong, I. H., Lee, S. W., Lee, Y. H., and Shim, H. S. 2010. Bacterial leaf spot of iceberg lettuce caused by Xanthomonas campestris pv. vitians type B, a new disease in South Korea. Plant Dis. 94:790.

Obradovic, A., Mavridis, A., Rudolph, K., Janse, J. D., Arsenijevic, M., Jones, J. B., Minsavage, G. V., and Wang, J. F. 2004. Characterization and PCRbased typing of Xanthomonas campestris pv. vesicatoria from peppers and tomatoes in Serbia. Eur. J. Plant Pathol. 110:285-292.

Pernezny, K., Raid, R., Stall, R., Hodge, N., and Collins, J. 1995. An outbreak of bacterial spot of lettuce in Florida caused by Xanthomonas campestris pv. vitians. Plant Dis. 79:359-360.

Pohronezny, K., Stall, R., Canteros, B., Kegley, M., Datnoff, L., and Subramanya, R. 1992. Sudden shift in the prevalent race of Xanthomonas campestris pv. vesicatoria in pepper fields in southern Florida. Plant Dis. 76:118-120.

Robinson, P., Jones, J., and Pernezny, K. 2006. Bacterial leaf spot of lettuce: Relationship of temperature to infection and potential host range of Xanthomonas campestris pv. vitians. Plant Dis. 90:465-470.

Sahin, F. 2000. First report of bacterial spot of lettuce caused by Xanthomonas campestris pv. vitians in Turkey. Plant Dis. 84:490.

Sahin, F., Abbasi, P., Ivey, M., Zhang, J., and Miller, S. 2003. Diversity among strains of Xanthomonas campestris pv. vitians from lettuce. Phytopathology 93:64-70.

Sahin, F., and Miller, S. 1997. Identification of the bacterial leaf spot pathogen of lettuce, Xanthomonas campestris pv. vitians, in Ohio, and assessment of cultivar resistance and seed treatment. Plant Dis. 81:1443-1446.
Sarkar, S., and Guttman, D. 2004. Evolution of the core genome of Pseudomonas syringae, a highly clonal, endemic plant pathogen. Appl. Environ. Microbiol. 70:1999-2012.

Scally, M., Schuenzel, E., Stouthamer, R., and Nunney, L. 2005. Multilocus sequence type system for the plant pathogen Xylella fastidiosa and relative contributions of recombination and point mutation to clonal diversity. Appl. Environ. Microbiol. 71:8491-8499.

Smith, J. M. 1999. The detection and measurement of recombination from sequence data. Genetics 153:1021-1027.

Smith, J. M., Smith, N. H., O’Rourke, M., and Spratt, B. G. 1993. How clonal are bacteria? Proc. Nat. Acad. Sci. USA 90:4384-4388.

Tajima, F. 1989. Statistical-method for testing the neutral mutation hypothesis by DNA polymorphism. Genetics 123:585-595.

Toussaint, V. 1999. Bacterial leaf spot, a new disease of lettuce in Quebec caused by Xanthomonas campestris pv. vitians. Phytoprotection 80:121-125.

Vaidya, G., Lohman, D. J., and Meier, R. 2011. SequenceMatrix: Concatenation software for the fast assembly of multi-gene datasets with character set and codon information. Cladistics 27:171-180.

Vauterin, L., Hoste, B., Kersters, K., and Swings, J. 1995. Reclassification of Xanthomonas. Int. J. Syst. Evol. Microbiol. 45:472-489.

Wang, Y., Lu, H., Raid, R. N., Nuessly, G. S., and Faroutine, G. 2015. Diverse responses of lettuce cultivars and germplasm lines to infections of three isolates of Xanthomonas campestris pv. vitians. HortScience 50:650-655.

Yan, S., Liu, H., Mohr, T. J., Jenrette, J., Chiodini, R., Zaccardelli, M., Setubal, J. C., and Vinatzer, B. A. 2008. Role of recombination in the evolution of the model plant pathogen Pseudomonas syringae pv. tomato DC3000, a very atypical tomato strain. Appl. Environ. Microbiol. 74:3171-3181.

Yigit, F. 2011. Acibenzolar-S-methyl induces lettuce resistance against Xanthomonas campestris pv. vitians. Afr. J. Biotechnol. 10:9606-9612.

Young, J. M., Park, D., Shearman, H. M., and Fargier, E. 2008. A multilocus sequence analysis of the genus Xanthomonas. Syst. Appl. Microbiol. 31: 366-377.

Zoina, A., and Volpe, E. 1994. Epidemiological Aspects of Lettuce Bacterial Spot Induced by Xanthomonas campestris pv. vitians. Pages 797-802 in: Plant-Pathogenic Bacteria. M. Lemattre, S. Freigoun, K. Rudolph, and J. G. Swings, eds. INRA Colloquia, Versailles, France. 